\author{
Dr. sc. Sanja Otočan \\ Visoki upravni sud Republike Hrvatske
}

\title{
NAČELO UČINKOVITOSTI UPRAVNOG SPORA U SVJETLU KONVENCIJSKOG PRAVA NA SUĐENJE U RAZUMNOM ROKU
}

UDK: $342.9: 347.932$

DOI: $10.31141 /$ zrpfs.2020.57.135.179

Pregledni znanstveni rad

Primljeno: 1. studenog 2019.

Prava iz članka 6. Konvencije za zaštitu ljudskih prava i temeljnih sloboda Vijeća Europe počivaju na ideji djelotvorne pravne zaštite. Suđenje u razumnom roku u uskoj je vezi s poimanjem poštenog suđenja o kojemu nije moguće govoriti u slučaju pretjerano duge neizvjesnosti stranaka u pogledu njihovih prava i obveza o kojima se odlučuje pred sudom. U tom je kontekstu za hrvatski upravni spor iznimno značajna 2012. godina u kojoj je zaživio bitno izmijenjen sustav upravnog sudstva u Republici Hrvatskoj. Pored nove organizacije upravnog sudstva i ovlasti upravnih sudova i Visokog upravnog suda proizašlih iz reforme upravnog sudstva u Republici Hrvatskoj, koja se odrazila i na trajanje upravnih sporova u Republici Hrvatskoj, novi je Zakon o upravnim sporovima u upravni spor ugradio mehanizme čija je svrha postizanje što veće učinkovitosti upravnih sudova. Važnost zahtjeva za bržim i efikasnijim upravnim sporom, kao i suđenjem u razumnom roku hrvatski je zakonodavac izrazio inkorporirajući načelo učinkovitosti u novi Zakon o upravnim sporovima kao jedno od temeljnih načela upravnosudskog postupka. Normativna rješenja Zakona o upravnim sporovima upućuju na zaključak da je tim Zakonom učinjen prvi korak usmjeren k učinkovitom upravnom sporu odnosno ostvarenju prava na suđenje u razumnom roku u upravnim stvarima, čime su stvorene normativne pretpostavke za poštovanje konvencijskog prava na donošenje odluke u upravnim stvarima u razumnom roku. Praksa upravnih sudova pokazuje da se upravni sporovi u pravilu vode u skladu s načelom učinkovitosti, što potkrepljuju i statistički podaci o prosječnom trajanju upravnih sporova u Republici Hrvatskoj koji ne izlaze izvan okvira razumnog roka prema standardima Europskog suda za ljudska prava. Ipak, uvažavajući potrebu uspostavljanja ravnoteže između zahtjeva za učinkovitim postupanjem suda i zahtjevima poštenog suđenja u ostalim aspektima koji bi u slučaju pretjeranog formalizma u tumačenju načela učinkovitosti, mogli biti dovedeni u pitanje, u svakom je konkretnom slučaju potrebno koristiti procesne mehanizme upravnog spora na način da oba zahtjeva budu zadovoljena.

Ključne riječi: konvencija, pravo na suđenje u razumnom roku, upravni spor, načelo učinkovitosti, efikasnost upravnih sudova 


\section{UVOD}

O pravnoj zaštiti nije moguće govoriti bez njezine djelotvornosti. Pravna zaštita koja ostaje na razini deklaracije i kojoj nedostaje djelotvornost ne može opravdati svoje postojanje jer ne ispunjava svrhu radi koje je ustanovljena. Međutim, još uvijek nisu uspostavljeni potpuno jasni kriteriji za definiranje i vrednovanje djelotvornosti, odnosno efikasnosti pojedinog pravnog sustava. ${ }^{1}$

Svaki pravni poredak utemeljen na načelima pravne države i vladavine prava teži što efikasnijem sustavu zaštite građanskih i ljudskih prava. Odlučivanje pred sudovima u razumnom roku u interesu je osobe koja zahtijeva da sud odluči o njezinim pravima ili obvezama ili o sumnji ili optužbi zbog kaznenog djela, ali i pravne sigurnosti, kao načela na kojemu se temelji objektivni pravni poredak zbog čega bi ono trebalo postati imperativ u svakoj državi koja teži ostvarivanju ideala vladavine prava. ${ }^{2}$

Pravni promet zahtijeva efikasno suđenje odnosno brzo okončanje sporova pa se pred sudove postavlja zadaća postupanja u skladu s načelom učinkovitosti. Efikasna pravda od iznimne je pravne i pravno-političke važnosti. Ona potiče brži i sigurniji opticaj kapitala i pridonosi stvaranju osjećaja pravne sigurnosti. ${ }^{3}$ Načelo učinkovitosti zauzima nezaobilazno mjesto u pružanju kvalitetne sudske zaštite. U tom smislu hrvatski procesni zakoni određuju da je sud dužan nastojati da se postupak provede bez odugovlačenja. ${ }^{4}$ Isto vrijedi i za upravni postupak ${ }^{5}$ i upravni spor. $^{6}$

Vrste i narav prava koja se ostvaruju u upravnom i upravnosudskom postupku upućuju na važnost pravodobnog odlučivanja u upravnim stvarima. Donošenje odluke o upućivanju na liječenje, o pravu na dječji doplatak, o nekom pravu iz

1 Više o tome, Uzelac, Alan, „Efikasnost pravosuđa u europskom kontekstu: usporedba funkcioniranja europskih pravosudnih sustava“, Zbornik Pravnog fakulteta u Zagrebu, 55:3-4/2005.

2 Neki autori iznose mnogo pragmatičnije razloge zbog kojih je državi u interesu odlučivanje u razumnom roku. Tako npr. Ivica Crnić ističe: “... odlučivanje u takvom (razumnom - op.) roku u interesu je i države koja financira rad sudstva, jer bi kraće trajanje postupaka za posljedicu trebalo imati manje financijske obveze države za potrebe funkcioniranja sudstva”, Crnić, Ivica, „Hrvatska sudbena vlast i pravo na suđenje u razumnom roku“, Hrvatska pravna revija, studeni 2002., str. 125.

3 Usp. Radolović, Aldo, ,Zaštita prava na suđenje u razumnom roku - realna mogućnost, (pre)skupa avantura ili utopija?“, Hrvatska pravna revija, travanj 2008., str. 7.

4 Članak 10. stavak 1. Zakona o parničnom postupku, Narodne novine, 53/91., 91/92., 112/99., 88/01., 117/03., 88/05., 2/07. - odluka Ustavnog suda Republike Hrvatske, 84/08., 96/08. - odluka Ustavnog suda Republike Hrvatske, 123/08., 57/11., 148/11. - pročišćeni tekst, 25/13., 89/14. - odluka Ustavnog suda Republike Hrvatske i 70/19., propisuje: "Sud, stranke i drugi sudionici moraju nastojati da se postupak provede bez odugovlačenja, u razumnom roku i sa što manje troškova. Sud je dužan onemogućiti svaku zlouporabu prava u postupku."

5 Članak 10. Zakona o općem upravnom postupku, Narodne novine, 47/09., uređuje načelo učinkovitosti i ekonomičnosti, propisujući: "U upravnim stvarima postupa se što je moguće jednostavnije, bez odgode i uz što manje troškova, ali tako da se utvrde sve činjenice i okolnosti bitne za rješavanje o upravnoj stvari." Raniji Zakon o općem upravnom postupku, Narodne novine, 53/91. i 103/96. - odluka Ustavnog suda Republike Hrvatske, sadržavao je načelo efikasnosti prema kojemu su tijela koja rješavaju u upravnim stvarima dužna osigurati efikasno ostvarivanje prava i interesa stranaka.

6 Zakon o upravnim sporovima, Narodne novine, 20/10., 143/12., 152/14., 94/16. - odluka Ustavnog suda Republike Hrvatske i 29/17., u članku 8. sadržava načelo učinkovitosti. 
područja socijalne skrbi i sl. nakon određenog vremena postaje bespredmetno budući da se u takvim slučajevima zakašnjelim odlučivanjem ne može postići svrha zbog koje je zahtjev podnesen.

\section{KONVENCIJSKO PRAVO NA SUĐENJE U RAZUMNOM ROKU}

Konvencija za zaštitu ljudskih prava i temeljnih sloboda (engl. Convention for the Protection of Human Rights and Fundamental Freedoms; franc. Convention de sauvegarde des droits de l'homme et des libertés fondamentales $)^{7}$ kao najznačajniji europski pravni akt kojim se jamče ljudska prava i razrađuje sustav njihove zaštite, u članku 6. stavku 1. uvodi faktor "vremena" kao bitan uvjet za ostvarivanje pravde.

Budući da bi dugotrajni sudski postupci mogli ugroziti efikasnost, ali i vjerodostojnost pravosuđa, Konvencija naglašava važnost provođenja pravde bez kašnjenja, propisujući da sudski postupci moraju biti okončani u razumnom roku. Konvencija u članku 6. stavku 1. jamči pravo na pošteno suđenje (right to a fair trial), koje objedinjuje više temeljnih procesnih prava, među kojima je i pravo na suđenje u razumnom roku.

Sustav procesnih prava iz članka 6 . Konvencije počiva na ideji djelotvorne pravne zaštite o kojoj nije moguće govoriti ako ona nije pravodobna. ${ }^{8}$ Svrha je članka 6. stavka 1. Konvencije u dijelu kojim se jamči suđenje u razumnom roku zaštititi stranke pred sudovima od prevelikih odugovlačenja postupaka te naglasiti važnost provođenja pravde bez kašnjenja koje bi moglo ugroziti učinkovitost i vjerodostojnost pravosudnih sustava. ${ }^{9}$

Suđenje u razumnom roku u uskoj je vezi s poimanjem poštenog suđenja o kojemu nije moguće govoriti u slučaju pretjerano duge neizvjesnosti stranaka u pogledu njihovih prava i obveza o kojima se odlučuje pred sudom. ${ }^{10}$ Svrha je

7 O Konvenciji opširno u: Omejec, Jasna, Konvencija za zaštitu ljudskih prava i temeljnih sloboda u praksi Europskog suda za ljudska prava, Strasbourški acquis, Novi informator, Zagreb, 2013.; Greer, Steven: The European Convention on Human Rights. Achievements, Problems and Prospects, Cambridge Studies in European Law and Policy, Cambridge, 2006.; Jacobs, Francis, Geoffrey; White, Robin C. A.; Ovey, Clare, The European Convention on Human Rights, Oxford, 2006.

8 Stara uzrečica "Justice rétive, justice fautive" (franc.) odnosno "Justice delayed justice denied" (engl.) najbolje ilustrira potrebu izbjegavanja dugotrajnih suđenja.

9 Opširnije o tome u: Goranić, Ivana, ,Suđenje u "razumnom roku” - jedan od uvjeta za pravično suđenje (članak 6. st. 1. Europske konvencije za zaštitu ljudskih prava i temeljnih sloboda)“, Vladavina prava. 6 (2000.), str. 51

10 Svrhu razumnog roka iz članka 6 stavka 1. Konvencije Goranić vidi u sljedećem: "Temeljna je svrha uvođenja pojma 'razumnog roka' u članku 6. Konvencije osigurati pravnu sigurnost, odnosno omogućiti dovoljnu brzinu rješavanja predmeta pred sudovima, kako bi se stranci omogućilo da ne bude predugo pod optužbom ili u neizvjesnosti u svezi sa svojim pravnim statusom, što - uz ostale - čini nezaobilazni uvjet za pravično suđenje. Cilj je postavljanja kriterija 'razumnog roka' i zaštita svih stranaka u postupku od odugovlačenja postupka. Neki postupci štete reputaciji osoba protiv kojih se vode, te ih je potrebno okončati u najkraćim rokovima, ali da to ne ide na štetu kvalitetne pripreme svih stranaka za suđenje. Odugovlačenje postupka također narušava kredibilitet i učinkovitost pravde koju su sudovi dužni provoditi." Goranić, Ivana, ,Suđenje u “razumnom roku” - jedan od uvjeta za pravično suđenje (članak 6. st. 1. Europske konvencije za zaštitu ljudskih prava i temeljnih sloboda)“. 
zahtjeva za razumnim rokom iz članka 6. stavka 1 . Konvencije pružanje jamstva da će pojedinačni slučaj pred sudom biti okončan unutar razumnog vremena, što znači da će vrijeme neizvjesnosti i nesigurnosti za stranku u postupku biti svedeno na prihvatljivu mjeru. ${ }^{11}$

Objedinjujući stajališta Europskog suda za ljudska prava glede zahtjeva iz članaka 6. stavka 1. i 13. Konvencije u vezi s djelotvornim pravnim sredstvom za zaštitu prava na razumnu duljinu sudskih postupaka, zahtjeve koji se postavljaju pred stranke ugovornice moguće je sažeti na sljedeće:

- Stranke ugovornice moraju organizirati svoje pravne sustave na način koji omogućava ostvarivanje jamstva na donošenje konačne odluke u sporovima koji se odnose na prava i obveze građanske naravi u razumnom roku.

- U slučaju nastanka povrede prava na suđenje u razumnom roku, nadležna nacionalna tijela moraju priznati povredu članka 6 . stavka 1 . Konvencije i onome tko je pretrpio povredu, dodijeliti primjerenu naknadu.

- Ako nacionalni pravni sustav ne omogućava ostvarivanje prava na suđenje u razumnom roku, potrebno je ustanoviti pravno sredstvo za ubrzavanje postupaka.

- Ako sudski postupci ne završavaju u razumnom roku, potrebno je ustanoviti "kompenzacijsko pravno sredstvo", bilo u obliku novčane naknade, bilo u nekom drugom obliku.

\section{POVREDE PRAVA NA SUĐENJE U RAZUMNOM ROKU PRED EUROPSKIM SUDOM ZA LJUDSKA PRAVA}

Duljina sudskih postupaka i neizvršavanje sudskih odluka predstavljaju najznačajniji problem funkcioniranja pojedinih pravosudnih sustava u Europi. Od 1959. do 2018. predmeti u kojima je utvrđena povreda prava na pošteno suđenje činili su gotovo $40 \%$ svih predmeta pred Europskim sudom za ljudska prava u kojima je utvrđena povreda nekog konvencijskog prava. ${ }^{12}$ Od toga, na povredu prava na suđenje u razumnom roku otpada 20,06\%.

Od stupanja na snagu Konvencije u Republici Hrvatskoj ${ }^{13}$ do 31. prosinca 2018., Europski sud za ljudska prava donio je 401 presudu protiv Republike Hrvatske. U 316 presuda utvrđena je povreda najmanje jednog konvencijskog prava. U 97 presuda utvrđena je povreda prava na suđenje u razumnom roku, što čini $30,7 \%$ svih utvrđenih povreda.

11 Detaljnije: Van Dijk, Pieter; Van Hoof, Fried, Theory and Practice of the European Convention on Human Rights, Antwerpen - Oxford, 2006., str. 511-651.

12 Overview 1959-2018 ECHR, European Court of Human Rights, March 2019, str. 6., www.echr. coe.int.

13 5. studenoga 1997. 
Unatoč smanjenju broja neriješenih predmeta pred hrvatskim sudovima u posljednjih nekoliko godina, broj neriješenih predmeta ${ }^{14}$ kao i trajanje određenih vrsta sudskih postupaka ${ }^{15}$ upućuju na zaključak da Republika Hrvatska (još uvijek) ulazi u skupinu zemalja s izraženim problemom prekomjernog trajanja sudskih postupaka. Taj se zaključak, međutim, ne može protegnuti i na postupke pred upravnim sudovima i Visokim upravnim sudom Republike Hrvatske (u daljnjem tekstu: Visoki upravni sud) koji upravne sporove rješavaju (u prosjeku) u rokovima koji nisu predugi sa stajališta konvencijskog prava na donošenje odluke u razumnom roku.

\section{UTJECAJ REFORME UPRAVNOG SUDOVANJA U REPUBLICI HRVATSKOJ NA TRAJANJE UPRAVNIH SPOROVA}

U višegodišnjoj raspravi koja je prethodila reformi upravnog sudstva u Republici Hrvatskoj prevladalo je mišljenje da je Republici Hrvatskoj potrebna reforma institucionalnog ustroja upravnog sudovanja kroz koju bi, između ostalog, bilo potrebno osigurati ostvarivanje svih procesnih jamstava poštenog suđenja iz članka 6. stavka 1. Konvencije.

Zakon o upravnim sporovima ${ }^{16}$ (u daljnjem tekstu: ZUS), koji je donesen 2010., a stupio na snagu 2012., značajno je izmijenio sustav upravnog sudstva u Republici Hrvatskoj. ${ }^{17}$ Svrha donošenja toga Zakona bilo je usklađivanje hrvatskog upravnosudskog postupka s pravnom stečevinom Europske unije i sa zahtjevima poštenog suđenja iz članka 6 . stavka 1 . Konvencije. ${ }^{18} \mathrm{U}$ to se vrijeme očekivalo da će procesna rješenja novoga ZUS-a doprinijeti efikasnijoj i učinkovitijoj upravnosudskoj zaštiti prava i pravnih interesa stranaka. ${ }^{19,20}$ Analizirajući novouspostavljenu ulogu

14 Prema podacima Ministarstva pravosuđa, na dan 31. prosinca 2018. na svim sudovima u Republici Hrvatskoj bilo je neriješeno 407.062 predmeta, što predstavlja smanjenje od $12 \%$ u odnosu na prethodnu godinu. Od toga broja pred upravnim sudovima i Visokim upravnim sudom bila su neriješena 11.183 predmeta. Statistički pregled za 2018. godinu, str. 9-11, www. pravosudje.gov.hr

15 Vidi Statistički pregled za 2018. godinu, str. 13, www. pravosudje.gov.hr

16 Zakon je donesen na sjednici Hrvatskog sabora 29. siječnja 2010., objavljen u Narodnim novinama broj 20/10., a stupio na snagu 1 . siječnja 2012.

17 Više o tome u Đerđa, Dario; Pičuljan, Zoran, „Nastanak i temeljni instituti novog Zakona o upravnim sporovima“, u: Europeizacija upravnog sudovanja u Hrvatskoj, Zagreb, 2014., str. 93-122.

18 Jedna od najvećih promjena odnosi se na provođenje usmene rasprave pred upravnim sudom. Opširnije o tome u: Karlovčan-Đurović, Ljiljana, „Usmena rasprava u upravnosudskom postupku“, Zbornik radova Pravnog fakulteta u Splitu, god. 47, 1/2010.

19 U tom smislu Galić, Rostaš-Beroš i Vezmar Barlek ističu: "Ideja vodilja u postupku izrade novog Zakona o upravnim sporovima bila je da se novim rješenjima hrvatsko upravno sudovanje približi europskim standardima upravnog sudovanja. Novi Zakon o upravnim sporovima svakako je sveobuhvatniji, moderniji te sadržava niz novih procesnih rješenja usmjerenih postizanju veće efikasnosti u upravnom sporu, a to bi kao povratni efekt trebalo dobiti bolju sudsku zaštitu." Galić, Ante; RostašBeroš, Lidija; Vezmar Barlek, Inga, Upravni spor u praksi, Tužbe, žalbe, ostali podnesci, presude, rješenja s napomenama i abecednim kazalom pojmova, Zakon o upravnim sporovima, Organizator, Zagreb, 2011 ., Predgovor.

${ }^{20} \mathrm{U}$ posljednje četiri godine koje su prethodile reformi (2008.-2011.), prosječno trajanje upravnosudskih postupaka iznosilo je oko 2,5 godine, a u razdoblju prije toga preko tri godine. 
upravnih sudova u sudskoj kontroli uprave u Republici Hrvatskoj, neki su autori isticali da novine koje je donio novi ZUS "pred suce upravnih sudova postavljaju vrlo tešku zadaću efikasnog postupanja koje mora biti usklađeno sa standardima pravne zaštite građana od povrede prava na suđenje u razumnom roku". ${ }^{21}$ Najveća promjena u institucionalnom ustroju upravnog sudstva u Republici Hrvatskoj uspostavljena novim ZUS-om dvostupanjsko je odlučivanje u upravnom sporu. Provođenje usmene rasprave u upravnom sporu pune jurisdikcije, ${ }^{22}$ koje je propisano kao pravilo te dvostupanjski upravni spor nedvojbeno predstavljaju pozitivan pomak u zaštiti prava stranaka ${ }^{23}$ i ostvarivanju nekih od ustavnih i konvencijskih zahtjeva. Međutim, s druge strane, postojala je realna opasnost da nova koncepcija upravnog spora već nakon nekoliko godina dovede u pitanje ostvarivanje prava na suđenje u razumnom roku u upravnosudskim postupcima. ${ }^{24}$ Ipak, novi ZUS sadržava rješenja koja sprečavaju opetovana vraćanja predmeta tuženim tijelima, ${ }^{25}$ što je u ranijem sustavu upravnog spora vrlo često dovodilo do prekomjernog trajanja postupaka.

Novi sustav upravnog sudovanja u Republici Hrvatskoj polučio je, kako pozitivan, tako i negativan utjecaj na ostvarivanje prava na suđenje u razumnom roku.

Pored nove organizacije upravnog sudstva i ovlasti upravnih sudova i Visokog upravnog suda proizašlih iz reforme upravnog sudstva u Republici Hrvatskoj, koja se odrazila i na trajanje upravnih sporova u Republici Hrvatskoj, novi je ZUS u sam upravni spor ugradio mehanizme čija je svrha postizanje što veće učinkovitosti upravnih sudova.

U prvih nekoliko godina novog sustava, novoustrojeni sudovi nisu imali značajnih zaostataka i relativno su uspješno mogli udovoljavati zahtjevu za suđenjem u razumnom roku. Pravo na žalbu protiv odluka prvostupanjskih sudova novim je ZUS-om bilo uređeno vrlo restriktivno ${ }^{26}$ zbog čega je Visoki upravni sud imao zanemariv priljev predmeta, što je rezultiralo kraćim ukupnim trajanjem postupka. U pravilu više nema mogućnosti višekratnog vraćanja predmeta upravnom tijelu

21 Šikić, Marko, „Pravo na suđenje u razumnom roku u upravnosudskim postupcima - novi problemi i izazovi“, u: Djelotvorna pravna zaštita u pravičnom postupku, Izazovi pravosudnih transformacija na jugu Europe, Liber amicorum Mihajlo Dika, ur. Uzelac, Alan, Garašić, Jasnica, Maganić, Aleksandra, Pravni fakultet Sveučilišta u Zagrebu, 2013., str. 979

22 Opširnije o sporu pune jurisdikcije vidi u: Britvić Vetma, Bosiljka; Ljubanović, Boris, „Posebnosti upravnog spora pune jurisdikcije“, u: Novosti u upravnoj $i$ upravnosudskoj praksi, Novi informator, Zagreb, 2015., str. 23-46.; Pičuljan, Zoran; Britvić Vetma, Bosiljka, ,Primjena i evolucija upravnog spora pune jurisdikcije“, Zbornik radova Pravnog fakulteta u Splitu, 47 (2010.), 1(95), str. 53-64.

23 Više o utvrđivanju činjenica i dokaznom postupku u upravnom sporu u: Rajko, Alen, ,Utvrđivanje činjenica i dokazni postupak u upravnom sporu“, Zbornik Pravnog fakulteta Sveučilišta u Rijeci (1991.), v. 34, br. 1, (2013.), str. 495-524.

24 O takvoj mogućnosti svjedoče iskustva u Republici Sloveniji. Zalar smatra da se "ekstenzivnom praksom suđenja na usmenim raspravama bitno ugrožava pravo na suđenje u razumnom roku". Zalar, Boštjan, Usmena rasprava - Problemi u praksi: Primjer Slovenije, Seminar za suce Vrhovnog i Upravnog suda Crne Gore, 4-5. prosinca 2008., Bečići, Crna Gora, www.sudovi.me/podaci/uscg/dokumenta/85.doc.

25 Prema ZUS-u, sud ima obvezu presudom riješiti upravnu stvar. Donošenje kasacijske odluke moguće je samo iznimno.

26 Člankom 66. stavkom 2. ZUS-a bilo je propisano da se žalba može podnijeti kada je upravni sud presudom sam odlučio o pravu, obvezi ili pravnom interesu stranke. 
na ponovni postupak, što je u razdoblju prije stupanja na snagu ZUS-a iz 2010. bio jedan od najčešćih razloga predugog trajanja postupaka u kojima se odlučuje u upravnim stvarima.

Unatoč nespornim pozitivnim stranama novog ustroja upravnog spora $\mathrm{u}$ Republici Hrvatskoj, određena zakonska rješenja ne idu u prilog ostvarivanju prava na suđenje u razumnom roku. Među takvim je rješenjima spor pune jurisdikcije u kojemu se u pravilu provodi usmena rasprava, utvrđuju činjenice i ocjenjuju dokazi, ${ }^{27}$ što u pravilu zahtijeva više vremena no što je potrebno za odlučivanje u sporu o zakonitosti upravnog akta (vrsta upravnog spora koja je prevladavala u razdoblju do 2012.). Nakon stupanja na snagu Zakona o izmjenama i dopunama ZUS-a, 2014. ${ }^{28}$ Žalba protiv presuda prvostupanjskih sudova postala je pravilo, ${ }^{29}$ čime se u određenoj mjeri produljilo ukupno trajanje upravnog spora. ${ }^{30}$

\section{NAČELO UČINKOVITOSTI UPRAVNOG SPORA}

Zahtjev za bržim i efikasnijim upravnim sporom, kao i suđenjem u razumnom roku obuhvaćen je načelom učinkovitosti kao jednim od temeljnih načela upravnosudskog postupka inkorporiranog u ZUS iz 2010. ${ }^{31}$ Ovo načelo zahtijeva od sudova vođenje upravnog spora brzo i bez odugovlačenja, izbjegavanje nepotrebnih radnji i troškova, sprečavanje zlouporabe prava stranaka i drugih sudionika u sporu i donošenje odluke u razumnom roku. ${ }^{32}$

Nakon analize različitih normativnih rješenja ZUS-a, može se zaključiti da je tim Zakonom učinjen prvi korak usmjeren k učinkovitom upravnom sporu odnosno ostvarenju prava na suđenje u razumnom roku u upravnim stvarima. ZUS-om iz 2010. stvorene su normativne pretpostavke za poštovanje ustavnog i konvencijskog prava na donošenje odluke u upravnim stvarima u razumnom roku.

Jedno od pozitivnih rješenja iz ZUS-a nalazimo u članku 32. stavku 2. kojim je određen vremenski raspon roka za dostavu odgovora na tužbu, propisujući da sud

27 Među različitim dokaznim prijedlozima u upravnom sporu stranke često predlažu provođenje dokaza sudskim vještačenjem, koje u pravilu, bitno produljuje postupak.

${ }_{28}$ Zakon o izmjenama i dopunama ZUS-a, Narodne novine, 152/14., stupio je na snagu 30. prosinca 2014

29 Zakonom o izmjenama i dopunama ZUS-a iz 2014. brisan je stavak 2. članka 66. ZUS-a koji je ograničavao pravo na žalbu protiv prvostupanjskih presuda te je u ZUS dodan članak 66.a koji glasi: „(1) Žalba nije dopuštena protiv presude kojom je pojedinačna odluka javnopravnog tijela poništena ili oglašena ništavom i predmet prvi put vraćen na ponovni postupak, kao ni protiv presude kojom je sud naložio donošenje pojedinačne odluke koja nije donesena u propisanom roku. (2) Protiv dijela presude iz članka 89. stavka 4. ovog Zakona u koji je uključen sadržaj sudske nagodbe žalba nije dopuštena.“

30 Prema statističkim podacima, žalbeni postupak pred Visokim upravnim sudom 2015. godine trajao je prosječno 61 dan, 2016. godine 119 dana, 2017. godine 153 dana, a 2018. godine 195 dana.

31 Načelo učinkovitosti uređeno je člankom 8. ZUS-a koji glasi: "Sud će upravni spor provesti brzo i bez odugovlačenja, uz izbjegavanje nepotrebnih radnji i troškova, onemogućit će zlouporabu prava stranaka i drugih sudionika u sporu te će odluku donijeti u razumnom roku."

32 Raniji Zakon o upravnim sporovima, Narodne novine, 53/91., 9/92. i 77/92., nije sadržavao sličnu odredbu. 
određuje rok za odgovor na tužbu prema okolnostima slučaja koji ne može biti kraći od osam niti dulji od 30 dana. . $^{33,34}$

Kao primjer norme koja je inspirirana načelom učinkovitosti upravnog spora valja spomenuti odredbu članka 34. stavka 1. ZUS-a kojom je propisano da su stranke obvezne u tužbi i odgovoru na tužbu iznijeti sve činjenice na kojima temelje svoje zahtjeve, predložiti dokaze potrebne za njihovo utvrđivanje i izjasniti se o činjeničnim navodima i dokaznim prijedlozima drugih stranaka.

Promatrano s aspekta zahtjeva za suđenjem u razumnom roku odnosno načela učinkovitosti sudova koji postupaju u upravnim sporovima, ovakvo normativno rješenje valja pozdraviti. Međutim, upitan je stvarni doseg te odredbe u praksi sudova s obzirom na to da ZUS ne propisuje nastupanje bilo kakvih negativnih posljedica za stranku koja ne postupi u skladu s tom odredbom. ${ }^{35}$

Osobit doprinos kraćem trajanju upravnog spora očekuje se od odredbe članka 23. stavka 3. ZUS-a koja propisuje obvezu tužitelja koji nema prebivalište, odnosno boravište ili sjedište u Republici Hrvatskoj da u tužbi naznači opunomoćenika ili opunomoćenika za primanje pismena. Naime, u predmetima u kojima su tužitelji izvan Republike Hrvatske, uobičajena dostava pismena diplomatskim putem traje

33 Ako bismo propisani vremenski raspon za dostavu odgovora na tužbu promatrali u svjetlu kompleksnosti tužbenih navoda u prosječnoj tužbi upravnim sudovima ili Visokom upravnom sudu, mogli bismo doći do zaključka da je maksimalni propisani rok od 30 dana u većini slučajeva predug $\mathrm{i}$ da ne postoji opravdani razlog za određivanje upravo takvog roka, već bi i znatno kraći rok bio dostatan tuženiku (i eventualno zaintreresiranim osobama) za pripremu i dostavu sudu kvalitetnog odgovora na tužbu. S druge strane, postoje složeni predmeti u kojima je opravdano odrediti rok od 30 dana za dostavu odgovora na tužbu.

34 Ovdje valja uputiti na pojavu neusklađenosti dvaju zakona koji uređuju postupanje Visokog upravnog suda u predmetima javne nabave u kojima je taj sud prva i posljednja instanca suđenja. Neusklađenost ZUS-a i Zakona o javnoj nabavi, Narodne novine, 120/16., dovodi do problema u praksi. Naime, Zakonom o javnoj nabavi propisano je da će se odluka u upravnom sporu pokrenutom protiv Državne komisije za kontrolu postupaka javne nabave donijeti u roku od 30 dana od dana podnošenja uredne tužbe. S druge strane, rok za dostavu odgovora na tužbu prema ZUS-u, ne smije biti kraći od osam dana, ali je dopušteno određivanje roka i od 30 dana, što u slučaju upravnog spora radi javne nabave, zbog roka za okončanje spora, nije primjenjivo. Unatoč nedvojbeno legitimnom cilju koji se ovakvim uređenjem trajanja upravnih sporova radi javne nabave želio postići, ne može se opovrgnuti činjenica da takvom uređenju (motiviranom isključivo željom za što kraćim trajanjem sudskih postupaka u ovoj vrsti upravnih stvari) nije prethodila analiza mogućih negativnih posljedica takvog zakonskog rješenja. Te se posljedice prije svega i u najvećoj mjeri odnose na potencijalni pad kvalitete sudskih odluka donesenih pod pritiskom vremenskog okvira postavljenog pozitivnim propisom, ali i na mogućnost uskraćivanja procesnih prava stranaka u toj vrsti postupaka, što se može negativno odraziti na zaštitu njihovih subjektivnih prava zbog kojih se postupci i vode.

35 Način na koji pojedini suci upravnih sudova vide tu odredbu razvidan je iz prakse prema kojoj se strankama ne priznaju troškovi za sastav podnesaka sastavljenih i dostavljenih sudu nakon podnošenja tužbe odnosno odgovora na tužbu, ako je riječ o podnescima koji sadrže navode koji su mogli odnosno morali biti izneseni u tužbi ili u odgovoru na tužbu. 
mjesecima, ponekad čak i godinama, što uzrokuje probleme u vođenju postupka te dovodi u pitanje ostvarivanje prava stranaka na suđenje u razumnom roku. ${ }^{36}$

Odredba ZUS-a koja dopušta rješavanje spora bez rasprave ${ }^{37}$ u određenom, manjem broju slučajeva, može doprinijeti kraćem trajanju upravnog spora. Ipak, s obzirom na vrlo restriktivno propisivanje pretpostavki za upravni spor bez rasprave,$^{38}$ nije realno očekivati ozbiljan doprinos zakonske mogućnosti vođenja spora bez rasprave ukupnom prosječnom kraćem trajanju upravnih sporova.

Nastojeći oživotvoriti načelo učinkovitosti, zakonodavac je propisao da se u upravnom sporu u pravilu zakazuje jedno ročište za raspravu radi izvođenja svih dokaza. ${ }^{39}$ Ta je odredba, osim u najsloženijim upravnim sporovima, zaživjela pa se u najvećem broju slučajeva rasprava zaključuje nakon prvog i jedinog ročišta.

Promatrajući učinkovitost upravnih sudova s aspekta stranaka koje sudjeluju u upravnim sporovima, najveći korak k ostvarivanju načela učinkovitosti zasigurno su ovlasti upravnih sudova u slučajevima u kojima utvrde osnovanost tužbenog zahtjeva. Naime, ako sud utvrdi da je pojedinačna odluka javnopravnog tijela nezakonita, usvojit će tužbeni zahtjev, poništiti pobijanu odluku i sam riješiti stvar, osim kada to ne može učiniti s obzirom na prirodu stvari ili je tuženik rješavao po slobodnoj ocjeni. ${ }^{40}$ Ako pak sud utvrdi da javnopravno tijelo nije u propisanom roku donijelo pojedinačnu odluku koju je prema propisima trebalo donijeti, presudom će usvojiti tužbeni zahtjev i sam riješiti stvar, osim kada to ne može učiniti s obzirom na prirodu stvari ili je tuženik rješavao po slobodnoj ocjeni. ${ }^{41}$ Takvo normativno rješenje, kojim je znatno ograničena mogućnost donošenja kasacijskih odluka upravnih sudova, već je u pravilu propisana dužnost donošenja reformacijskih odluka upravnih sudova, bitno smanjuje prostor za predugo trajanje postupka. Međutim, da bismo mogli govoriti o stvarnim efektima toga zakonskog rješenja, potrebno je ispitati u kojoj mjeri sudovi koriste tu svoju ovlast i donose reformacijske presude, što uvelike prelazi okvire ovoga rada. U međuvremenu možemo samo iznijeti vlastitu procjenu kako je znatno veći broj sporova u kojima se donose kasacijske presude umjesto

36 Međutim, u nekim je upravnim područjima, primjerice u području mirovinskog osiguranja, posebnim zakonom propisana iznimka od pravila o obvezi tužitelja koji boravi u inozemstvu da odredi opunomoćenika ili opunomoćenika za primanje pismena, čime se u upravnim sporovima iz toga upravnog područja uklonio, inače učinkovit, mehanizam za sprečavanje predugog trajanja postupaka. Ovakvo je rješenje osobito upitno s obzirom na predmet odlučivanja u upravnim sporovima iz toga upravnoga područja jer prema mjerilima Ustavnog suda Republike Hrvatske i Europskog suda za ljudska prava za ocjenu razumnosti trajanja postupaka, većina tih sporova ulazi u kategoriju sporova koji zbog važnosti za podnositelje zahtjeva, često i zbog njihove dobi, zahtijevaju brže postupanje sudova.

37 Članak 36. ZUS-a.

38 Prema članku 36. ZUS-a, sud može presudom riješiti spor bez rasprave: ako je tuženik priznao tužbeni zahtjev u cijelosti, u predmetu u kojem se rješava na temelju pravomoćne presude donesene $\mathrm{u}$ oglednom sporu, ako utvrdi da pojedinačna odluka, postupanje ili upravni ugovor sadržava nedostatke koji sprečavaju ocjenu njihove zakonitosti te ako tužitelj osporava samo primjenu materijalnog prava, činjenice su nesporne, a stranke u tužbi ili u odgovoru na tužbu izričito ne zahtijevaju održavanje rasprave.

39 Članak 37. stavak 5. ZUS-a.

40 Članak 58. stavak 1. ZUS-a.

41 Članak 58. stavak 3. ZUS-a. 
reformacijskih, koje bi, u skladu s jednim od temeljnih ciljeva reforme upravnog sudovanja u Republici Hrvatskoj 2012. godine, trebale prevladavati.

Ideju rješavanja upravne stvari u prvostupanjskom upravnom sporu, umjesto vraćanja predmeta javnopravnom tijelu na ponovni postupak, zakonodavac je protegnuo i na žalbeni postupak pred Visokim upravnim sudom propisavši da će Visoki upravni sud poništiti prvostupanjsku presudu, sam otkloniti nedostatke i presudom riješiti stvar ako utvrdi da je upravni sud počinio bitnu povredu pravila sudskog postupka, da je pogrešno ili nepotpuno utvrdio činjenično stanje ili da je pogrešno primijenio materijalno pravo. ${ }^{42}$ Cak i bez egzaktnih podataka o broju predmeta u kojima je Visoki upravni sud iskoristio tu svoju ovlast, moguće je izraziti sumnju u stvarni efekt takvog zakonskog rješenja. Za donošenje zaključaka o razlozima takvog stanja potrebno je istražiti stvarno stanje i utvrditi razloge nedovoljnog broja reformacijskih presuda u drugostupanjskom upravnom sporu.

\section{NAČELO UČINKOVITOSTI U PRAKSI UPRAVNIH SUDOVA}

Nastojeći voditi upravne sporove u skladu s načelom učinkovitosti, upravni sudovi koriste različite procesne mehanizme usmjerene na postizanje toga cilja. Korištenje tih procesnih mehanizama ilustrirat ćemo s nekoliko primjera.

U predmetu, poslovni broj: 6 UsI-979/17, Upravni sud u Osijeku usvojio je dokazni prijedlog za provođenje medicinskog vještačenja po ovlaštenom sudskom vještaku. Međutim, tužitelj nije uplatio predujam ni nakon pet mjeseci od donošenja rješenja kojim je pozvan na uplatu, već je predlagao produljenje roka. Sud nije prihvatio prijedlog, pozivajući se na načelo učinkovitosti, smatrajući da je tužitelju ostavljeno dovoljno vremena za uplatu predujma te da nije naveo niti jedan bitan razlog zbog kojega ga nije uplatio. ${ }^{43}$

U određenim situacijama tuženici svojim (ne)postupanjem mogu dovesti do odugovlačenja postupka. U predmetu Upravnog suda u Rijeci, poslovni broj: 3 UsI-1347/2018, tuženik u ostavljenom roku nije dostavio sudu odgovor na tužbu sa spisima koji se odnose na predmet spora, niti je dostavio cjeloviti spis predmeta, već samo dio spisa. Pozivajući se na načelo učinkovitosti, sud je riješio spor bez spisa predmeta, ${ }^{44}$ poništivši rješenje tuženika i vrativši predmet tuženiku na ponovni postupak. $^{45,46}$

42 Članak 74. stavak 2. ZUS-a.

43 Upravni sud u Osijeku, presuda, poslovni broj: 6 UsI-979/17 od 31. listopada 2018.

44 Upravni sud u Rijeci, presuda, poslovni broj: 3 UsI-1347/2018 od 8. siječnja 2019.

45 Slična je situacija u predmetima Upravnog suda u Rijeci, poslovni broj: 2 UsI-1404/15 (presuda od 2. svibnja 2017.) i Upravnog suda u Splitu, poslovni broj: 18 UsImio-852/18 (presuda od 28. studenoga 2018.).

46 Ovdje se već na prvi pogled javlja dvojba o učincima takvog postupanja u svjetlu ostvarivanja prava stranke na odlučivanje o njenim pravima i obvezama u razumnom roku. Naime, promatrajući slučaj s aspekta ukupnog trajanja postupka, upitno je hoće li stranka biti u boljoj poziciji nakon ovakvog postupanja suda ili bi sa stajališta trajanja postupka bilo uputnije pokušati pribaviti spis i okončati spor na način koji neće dodatno produljiti postupak. 
Ako stranke u tužbi odnosno odgovoru na tužbu izričito ne zahtijevaju održavanje rasprave, sudovi upravni spor rješavaju bez rasprave, pozivajući se na načelo učinkovitosti. ${ }^{47}$

Pojedine primjere postupanja sudova koja se obrazlažu pozivanjem na načelo učinkovitosti mogli bismo podvrgnuti kritici s obzirom na to da je u svakom pojedinom slučaju nužno uspostaviti ravnotežu između zahtjeva za učinkovitim postupanjem suda i zahtjevima poštenog suđenja koji bi u slučaju pretjeranog formalizma u tumačenju načela učinkovitosti, mogli biti dovedeni u pitanje.

Primjer u kojemu je postignuta ravnoteža između zahtjeva poštenog suđenja i načela učinkovitosti upravnog suda predmet je Upravnog suda u Splitu, poslovni broj: UsImio-278/16. Riječ je o upravnom sporu radi prava iz mirovinskog osiguranja u kojemu je provedeno sudsko vještačenje. Nalaz i mišljenje sudskog vještaka dostavljeni su strankama na očitovanje te im je određen rok od 15 dana radi dostavljanja očitovanja uz upozorenje da u slučaju dostavljanja očitovanja po proteku roka, ono neće biti predmetom razmatranja. Tuženik nije dostavio očitovanje o nalazu i mišljenju vještaka u roku koji je odredio sud, već je na ročištu koje je održano mjesec dana po proteku roka za dostavljanje očitovanja zatražio produljenje roka za dostavljanje očitovanja. Sud je odbio zahtjev, pozivajući se na načelo učinkovitosti. ${ }^{48}$

U predmetu upravnog suda u Zagrebu, poslovni broj: UsI-1323/18, radi poreza na promet nekretnina, tužitelj je tvrdio da je tržišna vrijednost nekretnina procijenjena nerealno s obzirom na njezinu lokaciju te mogućnost daljnje eksploatacije kao i pad tržišne vrijednosti nekretnina zbog recesije na tržištu zbog čega je predlagao vještačenje radi utvrđivanja vrijednosti nekretnina.

Tržišna vrijednost predmetnih nekretnina u upravnom je postupku utvrđena na temelju vještačenja stručnjaka sukladno članku 9a. Zakona o porezu na promet nekretnina. ${ }^{49}$ Uvidom u nalaz ovlaštenog vještaka sud je utvrdio da je vještak pri procjeni tržišne vrijednosti uzeo u obzir sve parametre koji umanjuju tržišnu vrijednost predmetnih nekretnina te zaključio kako je procjena obavljena sukladno Zakonu o porezu na promet nekretnina.

Sud je odbio dokazni prijedlog za provođenje sudskog vještačenja s obrazloženjem da tužitelj svojim navodima nije doveo u sumnju pravilnost utvrđenja upravnih tijela te da tužitelj samo tvrdi, a ničim ne dokazuje da bi se za predmetne nekretnine mogla postići niža cijena od one koja je utvrđena u upravnom postupku. Stoga sud nije našao svrsishodnim provoditi dokaz vještačenjem na okolnost utvrđivanja vrijednosti nekretnina, pozivajući se na načelo učinkovitosti. ${ }^{50}$

Primjer postupanja suda u skladu s načelom učinkovitosti upravnog spora koji treba slijediti u upravnim sporovima zbog šutnje uprave u svim onim slučajevima

\footnotetext{
47 Upravni sud u Osijeku, presuda, poslovni broj: 1 UsI-52/17 od 19. ožujka 2018.

48 Upravni sud u Splitu, presuda, poslovni broj: UsImio-278/16 od 13. srpnja 2018.

49 Zakon o porezu na promet nekretnina, Narodne novine, 69/97., 26/00., 153/02. i 22/11.

50 Upravni sud u Zagrebu, presuda, poslovni broj: UsI-1323/18-9 od 9. travnja 2019.
} 
u kojima to dopušta činjenični i pravni supstrat predmeta, nalazimo u predmetu Upravnog suda u Zagrebu, UsI-2501/14. U tom je predmetu bila riječ o šutnji drugostupanjskog javnopravnog tijela koje u zakonom propisanom roku nije odlučilo o tužiteljevoj žalbi protiv prvostupanjskog rješenja.

Sud je usvojio tužbeni zahtjev u dijelu u kojem je tužitelj tražio donošenje odluke o žalbi protiv prvostupanjskog rješenja i odlučio o žalbi.

Kao bitan dio obrazloženja presude kojom je usvojen tužbeni zahtjev u dijelu u kojem je zatraženo donošenje odluke o žalbi tužitelja, valja izdvojiti sljedeće:

„Člankom 8. Zakona ${ }^{51}$ određeno je da ce Sud upravni spor provesti brzo $i$ bez odugovlačenja, uz izbjegavanje nepotrebnih radnji i troškova, onemogućit će zlouporabu prava stranaka i drugih sudionika u sporu te će odluku donijeti u razumnom roku.

Promatrajući naprijed naznačenu odredbu, Sud uočava kako načelo učinkovitosti, propisano člankom 8. Zakona, nalaže sudu standard postupanja, sukladno kojem treba, uz izbjegavanje nepotrebnih radnji, osigurati zakonitost $i$ sudsku zaštitu prava i pravnih interesa fizičkih i pravnih osoba, a što je sadržajno cilj Zakona.

Člankom 58. stavak 3. Zakona propisano je da ako Sud utvrdi da javnopravno tijelo nije u propisanom roku donijelo pojedinačnu odluku koju je prema propisima trebalo donijeti, presudom će usvojiti tužbeni zahtjev i sam riješiti stvar, osim kada to ne može učiniti s obzirom na prirodu stvari ili je tuženik rješavao po slobodnoj ocjeni. Tada će tuženiku narediti donošenje odluke i za to mu odrediti primjereni rok.

Slijedom navedenog, Sud smatra da u slučaju u kojem je dopušteno izjaviti pravni lijek $i$ u kojem je taj lijek izjavljen, stranka ima na zakonu ustanovljeno legitimno očekivanje da će o tom lijeku i u propisanim rokovima, biti odlučeno te okolnost u kojoj javno pravno tijelo po propisanom pravnom lijeku ne postupa, pravo na pravni lijek čini formalnim propisom, izvan cilja zakona, a što po mišljenju ovoga Suda tada daje pravo stranci da se o njenom zahtjevu odluči u sporu pune jurisdikcije. Stoga Sud zaključuje da je u predmetima šutnje administracije tužbeni zahtjev sadržajno sastavljen od dva traženja i to prvotno da se donese rješenje koje u roku nije doneseno, ali i da se o zahtjevu odluči na način na koji stranka smatra da treba biti učinjeno. " 52

U konkretnom je slučaju sud odlučio o tužiteljevoj žalbi protiv prvostupanjskog rješenja, pozivajući se na članak 58. stavak 3. ZUS-a kojim je propisano da će sud, ako utvrdi da javnopravno tijelo nije u propisanom roku donijelo pojedinačnu odluku koju je prema propisima trebalo donijeti, presudom usvojiti tužbeni zahtjev i sam riješiti stvar (ako priroda stvari to dopušta).

Takvim se pristupom suda ostvaruje jedan od glavnih ciljeva reforme upravnog sudstva u Republici Hrvatskoj - učinkovito odlučivanje o pravima i obvezama stranaka u upravnim stvarima i onemogućavanje vraćanja predmeta javnopravnom tijelu na ponovni postupak.

51 ZUS-a.

52 Upravni sud u Zagrebu, presuda, poslovni broj: UsI-2501/14-24, od 28. prosinca 2016. 


\section{EFIKASNOST UPRAVNIH SUDOVA I VISOKOG UPRAVNOG SUDA}

\section{Upravni sudovi i Visoki upravni sud - trajanje upravnosudskih postupaka od 2013. do 2018., po godinama}

\begin{tabular}{|c|c|c|c|c|c|c|}
\hline Sud & 2013. & 2014. & 2015. & 2016. & 2017. & 2018. \\
\hline Zagreb & 393 & 429 & 531 & 619 & 373 & 324 \\
\hline Split & 186 & 342 & 425 & 169 & 164 & 105 \\
\hline Rijeka & 629 & 455 & 481 & 358 & 239 & 161 \\
\hline Osijek & 155 & 94 & 146 & 168 & 166 & 95 \\
\hline VUS & 233 & 68 & 61 & 119 & 153 & 195 \\
\hline
\end{tabular}

Izvor: Visoki upravni sud

Podaci iz tablice pokazuju (pozitivan) trend skraćivanja trajanja sporova pred sva četiri prvostupanjska upravna suda, dok se na Visokom upravnom sudu bilježi trend produljenja trajanja postupaka. Međutim, neovisno o sve duljem trajanju postupaka pred Visokim upravnim sudom, prosječno ukupno trajanje postupaka u dva stupnja još uvijek ne zove na uzbunu s aspekta prava na suđenje u razumnom roku. ${ }^{53}$

\section{ZAKLJUČAK}

Put do učinkovitog upravnog spora zahtijeva poduzimanje različitih mjera koje samo u svojoj ukupnosti mogu rezultirati ishodom kojim će biti zadovoljni svi sudionici u sporu, ali i društvo kao cjelina. Prije svega, nužno je zakonsko uređenje upravnog spora koje će biti u funkciji učinkovitog pružanja sudske zaštite. Gotovo jednako je važna i briga o ljudskim kapacitetima na kojima počiva efikasan sustav zaštite prava stranaka. Pored navedenog, iznimno je bitno kvalitetno normativno uređenje pojedinog upravnog područja i unapređenje kvalitete rada uprave što bi rezultiralo manjim brojem upravnih sporova, a posljedično i njihovim trajanjem $u$ skladu s ustavnim i konvencijskim pravom na suđenje u razumnom roku.

Reformom upravnog sudstva u Republici Hrvatskoj u dijelu koji se odnosi na promjenu institucionalnog ustroja upravnog sudovanja stvoreni su preduvjeti za učinkovito odlučivanje o pravima i obvezama stranaka u upravnim stvarima pred upravnim sudovima i Visokim upravnim sudom. S druge strane, sama normativna rješenja „novog“ upravnog spora pružaju sudovima adekvatan i dostatan ,alat“ za okončanje upravnih sporova u razumnom roku. Međutim, efikasnost upravnih sudova i Visokog upravnog suda u najvećoj mjeri ovisi o tome kako i u kojoj mjeri

53 Godine 2015. prosječno trajanje upravnog spora u dva stupnja iznosilo je 457 dana (15 mjeseci), 2016. godine 448 dana (15 mjeseci), 2017. godine 388 dana (13 mjeseci), a 2018. godine 366 dana (12 mjeseci). 
suci tih sudova koriste procesna ovlaštenja koja im ZUS stavlja na raspolaganje u funkciji učinkovitog odlučivanja o pravima i obvezama stranaka u upravnom sporu. Uvidom u praksu upravnih sudova može se zaključiti da ti sudovi u pravilu vode sporove u skladu s načelom učinkovitosti, ali postoje i primjeri iz kojih je razvidno da se to načelo shvaća na način koji onemogućava pravilno i potpuno utvrđivanje činjeničnog stanja $\mathrm{a}^{54} \mathrm{i} / \mathrm{ili}$ ostvarivanje različitih procesnih jamstava poštenog suđenja. U tom je smislu, u svakom pojedinom slučaju nužno uspostaviti ravnotežu između zahtjeva za učinkovitim postupanjem suda i zahtjevima poštenog suđenja u ostalim aspektima koji bi u slučaju pretjeranog formalizma u tumačenju načela učinkovitosti, mogli biti dovedeni u pitanje.

54 Tako se, primjerice, mogu pronaći slučajevi u kojima prvostupanjski upravni sud, pozivajući se na načelo učinkovitosti, odbija dokazni prijedlog stranke čije bi izvođenje zasigurno doprinijelo pravilnom utvrđivanju činjeničnog stanja. Postoje i primjeri u kojima se pozivom na načelo učinkovitosti stranci onemogućava raspravljanje pred sudom. 


\section{PRINCIPLE OF EFFICACY OF ADMINISTRATIVE DISPUTE IN THE LIGHT OF CONVENTION LAW OF THE RIGHT TO SPEEDY TRIAL}

Rights from Article 6 of the Council of Europe's convention of the protection of Human Rights and Fundamental Freedoms rest on the idea of effective legal protection. The right to a speedy trial is closely related to the concept of a fair trial which cannot be in the case of exaggerated lengthy uncertainty of parties in relation to their rights and obligations to be decided upon before the court. In this context, Croatian administrative dispute the year 2012 was exceptionally significant when a significantly changed system of administrative adjudication in the Republic of Croatia occurred. Besides this new organisation of administrative adjudication and administrative court and High Administrative Court powers emerging from administrative court reforms in the Republic of Croatia which also reflected on the duration of administrative disputes in the Republic of Croatia, the new Administrative Dispute Act in administrative dispute built in mechanisms the purpose of which is to achieve maximum efficiency of administrative courts. The Croatian legislator expressed the importance of demands for speedy and effective administrative dispute, as well as speedy trial, in the incorporation of the principle of effectiveness in the new Administrative Dispute Act as one of the fundamental principles of administrative court procedure. Normative solutions of the Administrative Dispute Act imply the conclusion that this law is the first step towards efficient administrative dispute or achieving rights to speedy trial for administrative matters. This creates normative presumptions for respecting convention rights to reaching decisions in administrative matters within a reasonable timeframe. Administrative court practice shows that administrative disputes in principle are carried out according to the principle of efficacy. This is supported by statistical data on the average duration of administrative disputes in the Republic of Croatia, which do not exceed a reasonable timeframe according to European Court of Human Rights' standards. However, taking into account that the need to establish a balance between the demand for efficient court procedure and the demand for the right to fair trial in other aspects could be called into question in the case of exaggerated formalism in the interpretation of the principle of effectiveness. In every concrete case, it is necessary to use the process mechanisms of administrative dispute in a way that both demands are met.

Key words: convention, right to speedy trial, administrative dispute, principle of efficacy, administrative court efficiency 